\title{
Erratum to: Application of the Molecular Invariom Model for the Study of Interactions Involving Fluorine Atoms in the $\left\{\mathrm{Yb}_{2}^{\mathrm{II}}\left(\mu_{2}-\mathrm{OCH}\left(\mathrm{CF}_{3}\right)_{2}\right)_{3}(\mu 3-\right.$ $\left.\mathrm{OCH}\left(\mathrm{CF}_{3}\right)_{2}\right)_{2} \mathrm{Yb}^{\mathrm{III}}\left(\mathrm{OCH}\left(\mathrm{CF}_{3}\right)_{2}\right)_{2}\left(\mathrm{THF}_{2}\left(\mathrm{Et}_{2} \mathrm{O}\right)\right\}$ Complex
}

\author{
R. V. Rumyantsev ${ }^{a}$, G. K. Fukin ${ }^{a}, *$, E. V. Baranov ${ }^{a}$, A. V. Cherkasov ${ }^{a}$, and E. A. Kozlova ${ }^{a}$ \\ ${ }^{a}$ Razuvaev Institute of Organometallic Chemistry, Russian Academy of Sciences, Nizhny Novgorod, Russia \\ *e-mail: gera@iomc.ras.ru \\ Received June 21, 2021; revised June 21, 2021; accepted June 21, 2021
}

DOI: $10.1134 / \mathrm{S} 1070328421340017$

The article "Application of the Molecular Invariom Model for the Study of Interactions Involving Fluorine Atoms in the $\left\{\mathrm{Yb}_{2}^{\mathrm{II}}\left(\mu_{2}-\mathrm{OCH}\left(\mathrm{CF}_{3}\right)_{2}\right)_{3}(\mu 3-\mathrm{OCH}-\right.$ $\left.\left.\left(\mathrm{CF}_{3}\right)_{2}\right)_{2} \mathrm{Yb}^{\mathrm{III}}\left(\mathrm{OCH}\left(\mathrm{CF}_{3}\right)_{2}\right)_{2}(\mathrm{THF})\left(\mathrm{Et}_{2} \mathrm{O}\right)\right\}$ Complex", written by R. V. Rumyantsev, G. K. Fukin, E. V. Baranov, A. V. Cherkasov, and E. A. Kozlova, was originally published electronically in Springer-Link on 14 April 2021 without Open Access. After publication in volume 47, issue 4, pages 235-243 the authors decided to make the article an Open Access publication. Therefore, the copyright of the article has been changed to (C) The Author(s) 2021 and the article is forthwith distributed under the terms of a Creative Commons Attribution 4.0 International License (http://creativecommons.org/licenses/by/4.0/, CC BY), which permits use, duplication, adaptation, distribution and reproduction of a work in any medium or format, as long as you cite the original author(s) and publication source, provide a link to the Creative Commons license, and indicate if changes were made.

The original article can be found online at https://doi.org/10.1134/S1070328421020056 